\title{
КУЛЬТУРА ТА МИСТЕЦТВО В НЕОМАРКСИСТСЬКИХ ВЧЕННЯХ ФРАНКФУРТСЬКОї ШКОЛИ
}

\begin{abstract}
Д.М. Скальська
Справедливо зауважити, що проблеми підняті в свій час Марксом вказували на складність їх практичної реалізації, в той час як сам факт спроби застосування методу Маркса для трансформації настанов його системи дав плідні і результативні наслідки в неомарксизмі.

Так, Франкфуртська школа виявилась найбільш впливовим явищем та стала відомою такими її провідними представниками, як М. Хоркхаймер, Г. Маркузе, Е. Фромм, Г. Адорно, Ю. Хабермас. Вони, власне, й звернулись до ідей раннього Маркса з його концепцією відчуження людини, поєднавши її з критикою буржуазного суспільства та політичною стратегією держав, що були комуністично налаштовані. В ï концепціях марксистський соціоцентризм переплавляється в «критичну теорію» культури, мистецтва та суспільства.

Часто виникає запитання про адекватність підходу, за якого соціоцентричне вчення Маркса по праву можна віднести до антропологічної традиції сучасної західної філософії. Слід зважити на те, що концепція Маркса розвивалась в специфічному соціальному і теоретичному середовищі. В ньому вже був закладений антропологічний принцип, висунутий наукою в XIX ст., який заявляв людину як конкретну, цілісну істоту і водночас як мету філософського аналізу. Вагоме значення при цьому мав той факт, що індивідуальний розвиток і свобода, а відповідно і проблеми відчуження людини, розглядались у зв'язку з проблемами культури.

Отже, обгрунтування антропологічної налаштованості марксист-
\end{abstract}

Актуальні проблеми духовності 
ської спадщини можна сприймати принаймні у двох аспектах: пояснення філософського підходу Маркса до проблеми людини і культури та вагомість теоретичного і методологічного значення цього підходу для розвитку сучасної теорії культури. Насправді, мова заходить про теоретико-методологічні зв' язки між філософською концепцією людини як загальною теоретичною системою і концепцією культури як іманентним її компонентом. Антропологічна мотивація для неомарксизму була закладена в тій же теоретичній рефлексії про «родову» характеристику людини, про якісну специфіку людського буття в культурі і принципах ¥ї саморозвитку. Власне через культуру виражається найбільш яскраво і переконливо родова специфіка суб'єкта з його комплексом якісних характеристик - людською діяльністю, універсальністю, мораллю, раціональністю, естетичною рефлексією.

Чи можна, у зв'язку з цим, покладатись на термін «неомарксистська антропологія» і виводити з нього ретроспективний погляд на таке явище, зокрема, як ревізіонізм, прогнозуючи його позитивні чи негативні наслідки? В 60-х роках ХХ ст. виникла свого роду мода не лише дискутувати, а й фальсифікувати окремі положення, спекулювати на «творчій обробці» марксизму. Історії відомі факти ототожнення гуманістично-антропологічних рис класичного марксизму з вченням про «тотальну людину», «конкретну утопію», що стали теоретичною основою концепцій «філософа надії» Е. Блоха, «абстрактного гуманіста» Б. Фішера, діяча «Праксису» Г. Петровича, М. Кангрі та ін.

В 70-х роках в Радянському Союзі проводилась активна агітація за «чистоту» та високі ідеали марксизму і пропагування його гуманістичних ідей, що, як це не парадоксально, призвело до протиставлення марксизму філософській антропології: «На противагу всім різновидам буржуазної філософської антропології, марксистська філософія людини, утверджуючи пріоритет гуманістичного принципу, першорядне значення в людській діяльності надає ідеалам та цінностям революційної практики. I в цьому - її велика гідність як справжньої філософії творчої активності людини» [2, с. 181]. Одним із авторитетних проявів ревізіонізму більшість авторів тієї пори вважали діяльність Франкфуртської школи, особливо в 30-ті роки минулого століття.

Насправді, основні зусилля Франкфуртської школи протягом багатьох років були направлені на роз'яснення з критичних позицій як суперечностей, так і заповітів класичної філософії та її спадкоємців. 3 роками відбулось все більше наближення їі до царини літератури і мистецтва. Зокрема, це очевидно з праць Адорно та Маркузе, вершиною наукової кар'єри кожного з яких стали наукові публікації з естетики. 
Отже, визначати неомарксизм як критичну теорію лише з огляду на непричетність їі до класового вчення чи матеріалістичної філософії, в значенні методології, мабуть недостатньо. Ось що стверджує англійський марксолог Перрі Андерсон: «За останні роки існування західного марксизму дійсно можна вести розмову про справжню гіпертрофію естетики, яка виявилася переповненою всіма цінностями, які пригнічувались чи заперечувались в інших напрямках в силу виснаження соціалістичної політики» [1, с. 163].

Те, що в західному марксизмі відбулась така переорієнтація естетичного знання в бік поглибленого вивчення мистецтва як суттєвої частини свого предмету, в принципі, передбачив ще Маркс. Він витлумачував естетичне як внутрішню єдність суб'єкта з предметом. Маючи на увазі естетичну творчість як один із способів освоєння світу, Маркс підкреслював, що вона починається там, де сама творчість цілком грунтується на специфічному відношенні суб'єкта і об'єкта, на так званій «універсальній мірі». В ній і полягала суперечність, діалектична єдність двох полюсів відношення, що виключало їх злиття і протистояння, їх тотожність і контрастність. В такому ключі для неомарксизму виступає художня культура, яка, хоч і не охоплює всю сферу естетичної свідомості суспільства, все ж виступає особливо цілісною і розвинутою формою естетичної свідомості і естетичного відношення людини до дійсності.

Не оминув такий стан справ і Франкфуртську школу, яка протягом майже 40 років уособлювала інтелектуальну спробу дати оцінку політичним реаліям XX ст., його внутрішній драмі. Займаючи позицію опонування до всього існуючого, франкфуртці об'єднали в своїх концепціях гегельянізований марксизм з найновішими тенденціями сучасної західної філософії (перш за все «лівим» фрейдизмом) на основі соціологізації філософських понять. Свої погляди вони називали «критичною теорією суспільства», претендуючи бути одночасно філософською соціологією і соціологічною філософією. На формування Франкфуртської школи мали також вплив ідеї, запозичені з ніцшеанськи орієнтованої «антропологічної» соціальної філософії та соціології (Фрайєр, Шельські).

Проблематика відчуження (в дусі гегелівського та неогегельянського ототожнення відчуження і опредмечування), а також проблематика раціональності («раціоналізації), запозичена у Вебера, - наскрізні мотиви франкфуртської теорії. Однак, що стосується естетичних поглядів, то споріднює їх всіх ідея мистецтва як заперечення «тотального відчуження» «пізньобуржуазного» суспільства. Основу антропологі- 
чних пошуків Франкфуртської школи склали два етапи в її діяльності. Першим поштовхом стало обговорення опублікованих в 1932 році німецькою мовою марксових «Економічно-філософських рукописів 1844 року» $\mathrm{i}$ «Німецької ідеології» з метою протиставлення гуманістичної спадщини молодого Маркса нацистській ідеології та пропаганді «нового порядку».

Другим теоретичним джерелом послужила книга Д. Лукача «Історія і класова свідомість» (1923), якою вже на той час пожвавлено цікавились антропологічно налаштовані католицькі та екзистенціалістські кола. Щодо інтерпретації праць молодого Маркса, то вони набули значення «антропологічного гуманізму» або «філософії практики» $\mathrm{i}$ склали не обов'язково, як зазначається у більшості критичної літератури радянського періоду, явище ревізіонізму, а здійснили «антропологічний поворот» в ренесансі марксизму.

Звинувачення франкфуртців у догматизмі не виправдало себе, бо саме вони зуміли в ранніх працях Маркса відшукати образ людини в надкласовому значенні, людини - як взірця гуманізму, а відчуження праці подати з позиції гегелівського опредметнення духу. Єдність теорії та практики для них - діалектичний процес, а не «революційна зброя» соціалістичних перетворень. Вплив Франкфуртської школи був надто значним, особливо в галузі соціології культури та мистецтва, а затим в сфері соціологічної методології та «макросоціології», що сприяло поширенню неомарксизму у ФРН, США, Франції та Італії.

Програмними дослідженнями «критичної теорії» виступили праці М. Хоркхаймера «Матеріалізм та метафізика» (1933), а особливо «Традиційна та критична теорія» (1937) в його книзі «Діалектика просвіти» (1947, у співавторстві з Т. Адорно), в яких і формуєтсья оригінальний тип філософування Франкфуртської школи. Основним об'єктом виступає не соціальність, а сам тип культури як компонент західної цивілізації, раціональності, в межах якої функціонують і капіталізм, і соціалізм. Таким чином, у 30-40-х роках XX ст. марксистська теорія культури в творчості франкфуртців виступила свого роду «откровенням» (відрадою) в реакційному процесі дегуманізації культури і мистецтва.

Антропологічні ідеї у представників Франфуртської школи формувались на основі того, що культура, як така, виступала для них однозначно синонімом духовної культури, а визначальними в ній $\epsilon$ фiлософія та мистецтво. Більшість 3 франкфуртців виходили з того, що «найбільш німецьким з мистецтв» слід вважати літературу та музику, а одним з методів пізнання світу і людини є однозначно філософія. 
Вона ж склала феномен самопізнання культури: з одного боку, - як світогляд; з другого,- як творчість; з третього, - як побудова нового теоретичного знання.

Здатність філософії культури усвідомлювати та відображати суперечності соціальної реальності, ідеї, фетиші, ідеали, їх описувати у взаємодії всіх функціональних елементів породили як мінімум два дослідницькі інтереси: буття культури та свідомість культури. Посилаючись на «Феноменологію духу» Гегеля як еталонну систему та залучивши «Капітал» Маркса, франкфуртці проектують свою власну «науку про дух», спрямовуючи її критику на «традиційні теорії», які на їхню думку виявились байдужими до питань людини, її соціальноантропологічного статусу.

Культура та мистецтво в неомарксистській позиції франкфуртців виступають не лише як ознака духовної активності людей, а як єдність ïx духовної та матеріальної діяльності, що надає можливість зайняти позицію «аутсайдерства» в соціумі. Окремою увагою наділяється особистість критика, теоретика, мислителя, тобто розрізняється «академічний» (представник класики) носій філософських рефлексій та нескорений, войовничий «критичний теоретик». Якщо перший-нездатний поєднати, «пропустити» соціальні події через своє внутрішнє Я, то для другого - це єдиний і «найбажаніший» клопіт [4, с. 170].

В такому контексті аналізується життєдіяльність філософа - професіонала, багато в чому співзвучна спеціальним з даної теми розробкам К. Маннгейма та М.Вебера. Щоправда, в їхній соціологї розрізняється вчений-спеціаліст та вчений-громадянин. Так чи інакше, в пошуку розв'язки всіх антиномій франкфуртці схильні розшукувати носія «істинної свідомості», апелюючи до людського елементу.

Така логіка у виборі нового суб'єкта дослідження приводить їх до людини, що екзистує, творить буття-для-себе, позбавлене корупції фальшивого буржуазного суспільства. Дехто з теоретиків Франкфуртської школи знаходив близькість між політичними лозунгами «критичної теорії» та аксіомами німецького класичного ідеалізму, точніше, «етичними максимами всієї традиційної раціоналістичної філософії» [5, с. 121]. В кожному разі, відмінність «критичної теорії» суспільства від традиційної, очевидно, полягала в актуалізації антропологічних проблем, в постановці їх щодо культури та мистецтва як першочергових.

Неомарксистська антропологія знайшла своє продовження в творчій спадшині Л. Коллетті, Л. Альтюссера, Ю. Хабермаса, Е. Фромма та багатьох інших представників західної інтелігенції. Вже в 70-х роках, 
які позначені розпадом Франкфуртської школи, а також після офіційного завершення її діяльності, естетичні ідеї неомарксизму стали невід'ємною частиною антропологічного процесу. Особливо вони надихали неупереджену молодь в її демократичних рухах та процесах антивоєнних, феміністських, екологічних тощо.

Якщо взяти до уваги традицію західного марксизму в цілому, то зауважимо, що, незважаючи на всі труднощі, які випали на його долю, все ж більшість його представників не пішли шляхом реформізму. По-перше, майже всі неомарксисти займались філософією професійно, особливо, відкривши для себе ранні праці Маркса. По-друге, їхн діяльність носила епістемологічний характер і була налаштована на постійний пошук адекватного методу. По-третє, основним полем застосування методологічних розвідок, «органоном» філософії стала естетика та культура. По-четверте, всі інші намагання прориву поза естетикою, практикування нових тем (відсутніх в традиціях класичного марксизму) перетворювались в спекулятивні форми та переживали філософський песимізм. Мистецтво ж виступило справжньою втіхою та надією.

\section{1 Бібліографія}

[1] Андерсон П. Размышления о западном марксизме; На путях исторического материализма. / Пер. с англ.-M.: ИНТЕР-BЕРСО, 1991.

[2] Буржуазная философия ХХ века. - М.: Политиздат, 1974.

[3] Крымский C.Б. Философия как путь человечности и надежды. К.: Изд-во Курс, 2000.

[4] Horkheimer M. Kritiche Theorie. - Frankfurt am Main, 1968.

[5] Horkheimer M. The Eclipse of Reazon.-New York, 1947. 